\title{
HABITAT USE OF AGE - 0 TWAITE SHAD \\ (ALOSA FALLAX LACÉPĖDE, 1803) IN THE TIDAL FRESHWATER REGION OF THE ELBE RIVER, GERMANY.
}

\author{
M. GERKENS, R. THIEL
}

University of Hamburg, Institute of Hydrobiology and Fishery Science, Elbelab, Große Elbstraße 268, 22767 HAMBURG, Germany.

\begin{abstract}
Between April and August 1997 the distribution of twaite shad larvae in the lower Elbe River downstream the city of Hamburg was examined by ring net, lift net and pop net sampling. During each haul six environmental parameters - water depth, water temperature, conductivity, oxygen concentration, distance from shore line and distance from river channel - were estimated. Twaite shad larvae were found from 26 May to 10 July. Yolk sac larvae were present from 26 May to 25 June. High abundances of twaite shad larvae were found in the side channels and main channels. A canonical correspondence analysis was calculated to evaluate the importance of measured environmental parameters for the distribution of age - 0 fishes. Water depth, distance from shore line and distance from river channel were identified as main parameters for the distribution of species. Twaite shad larvae preferred maximum water depth and distance from shore line and short distances to the river channel. An upstream displacement of the spawning grounds of twaite shad was observed, following a trend first noticed in the early $90^{\text {th }}$. Nowadays, the location of spawning grounds corresponds to the situation at the beginning of the $19^{\text {th }}$ century. Reduced water pollution is believed to be the main reason for this phenomenon.
\end{abstract}

Key-words : twaite shad, Alosa fallax, larvae, River Elbe, habitat preference.

\section{STRATÉGIES D'UTILISATION DE L'HABITAT PAR LES ALEVINS D'ALOSE FEINTE (ALOSA FALLAX LACÉPĖDE,1803) DANS LA RÉGION D'EAU DOUCE À MARÉE DE LA RIVIĖRE ELBE, ALLEMAGNE.}

\section{RÉSUMÉ}

La distribution des larves d'alose feinte dans la rivière Elbe, en aval de Hambourg, a été examinée entre avril et août 1997 par capture d'individus à la seine, au carrelet et au filet à ballast. Parallèlement aux prises six paramètres environnementaux ont été mesurés: profondeur, température de l'eau, conductivité, concentration d'oxygène, distance par rapport à la rive et par rapport au courant fluvial. Des alevins d'alose feinte ont été capturés entre le 26 mai et le 10 juillet. Les alevins vésiculés étaient présents dans les captures effectuées entre le 26 mai et le 25 juin. Une abondance élevée fut observée dans les canaux latéraux ainsi que dans le courant principal. L'effet des facteurs 
environnementaux sur la répartition des larves a été calculé par analyse canonique des correspondances. Les larves d'alose feinte préfèrent les milieux profonds à l'écart de la rive et proches du courant principal. Un déplacement en amont de la frayère d'alose feinte fut observé, correspondant à une tendance auparavant notée au début des années 90 . Aujourd'hui l'emplacement des frayères correspond à la situation observée au début du $19^{\text {eme }}$ siècle. II est probable que l'amélioration de la qualité de l'eau de la rivière Elbe soit la cause principale de ce phénomène.

Mots-clés : alose feinte, Alosa fallax, larves, rivière Elbe, préférences d'habitat.

\section{INTRODUCTION}

The twaite shad (Alosa fallax Lacépède,1803) is distributed in the Mediterranean Sea, Baltic Sea and North Atlantic areas (KARTAS, 1981 ; TAVERNY, 1991). The species, which was very common in most European rivers at the beginning of the $19^{\text {th }}$ century, is nowadays very rare or completely extinct in a number of rivers. There are just a few rivers left with strong populations like the Garonne-Dordogne riversystem in France or the Elbe River in Germany (QUIGNARD and DOUCHEMENT, 1991a). The main reasons for the decline of stocks are the construction of weirs and water pollution which make it difficult for twaite shads to reach their original spawning grounds to reproduce successfully. In most North Atlantic rivers spawning grounds are located in the lower river parts just above the brackish water zone in regions with tidal influence (e.g. MOHR, 1941), but the length of spawning migration and the shape of spawning sites are quite variable. For the Rhine River it is known that in former times a part of the stock performed long migrations to upstream spawning areas near the city of Bonn (BARTL and TROSCHEL, 1997), whereas the main spawning grounds were located in the lower Rhine. For twaite shad migrating upstream the Rhone River a migratory distance of over $700 \mathrm{~km}$ was documented (QUIGNARD and DOUCHEMENT, 1991b). In some tributaries of the River Severn in England the twaite shad migrates to the upper parts of the river to spawn on gravel (CASWELL and APRAHAMIAN, 2000). This indicates a strong flexibility concerning habitat preferences in spawning and nursery areas. Therefore, reasons for differences in recruitment success can probably be found in the habitat conditions on spawning and nursery grounds, especially because mortality during this part of the life cycle is extremely high. In this regard the knowledge of specific habitat preferences of early developmental stages of twaite shad need to be improved.

The aims of this study were :

- to estimate the occurrence, density and distribution of twaite shad larvae in the main nurseries of the tidal Elbe River,

- to identify preferred habitat parameters of twaite shad larvae.

\section{MATERIAL AND METHODS}

\section{Study area}

The Elbe River is $1100 \mathrm{~km}$ long and has a catchment area of $148000 \mathrm{~km}^{2}$. The estuary covers an area of about $865 \mathrm{~km}^{2}$. The lower Elbe River is under tidal influence and can be divided in brackish water zone, freshwater zone, inland delta area and upper tidal Elbe (Figure 1). Due to channelisation the water depth in the main channel downstream the city of Hamburg is deeper than $15 \mathrm{~m}$ and current velocities reach $2 \mathrm{~m} . \mathrm{sec}^{-1}$ during flood 
tide. Side channels, bays and tributaries with lower current and water depth exist besides the deepened waterway.

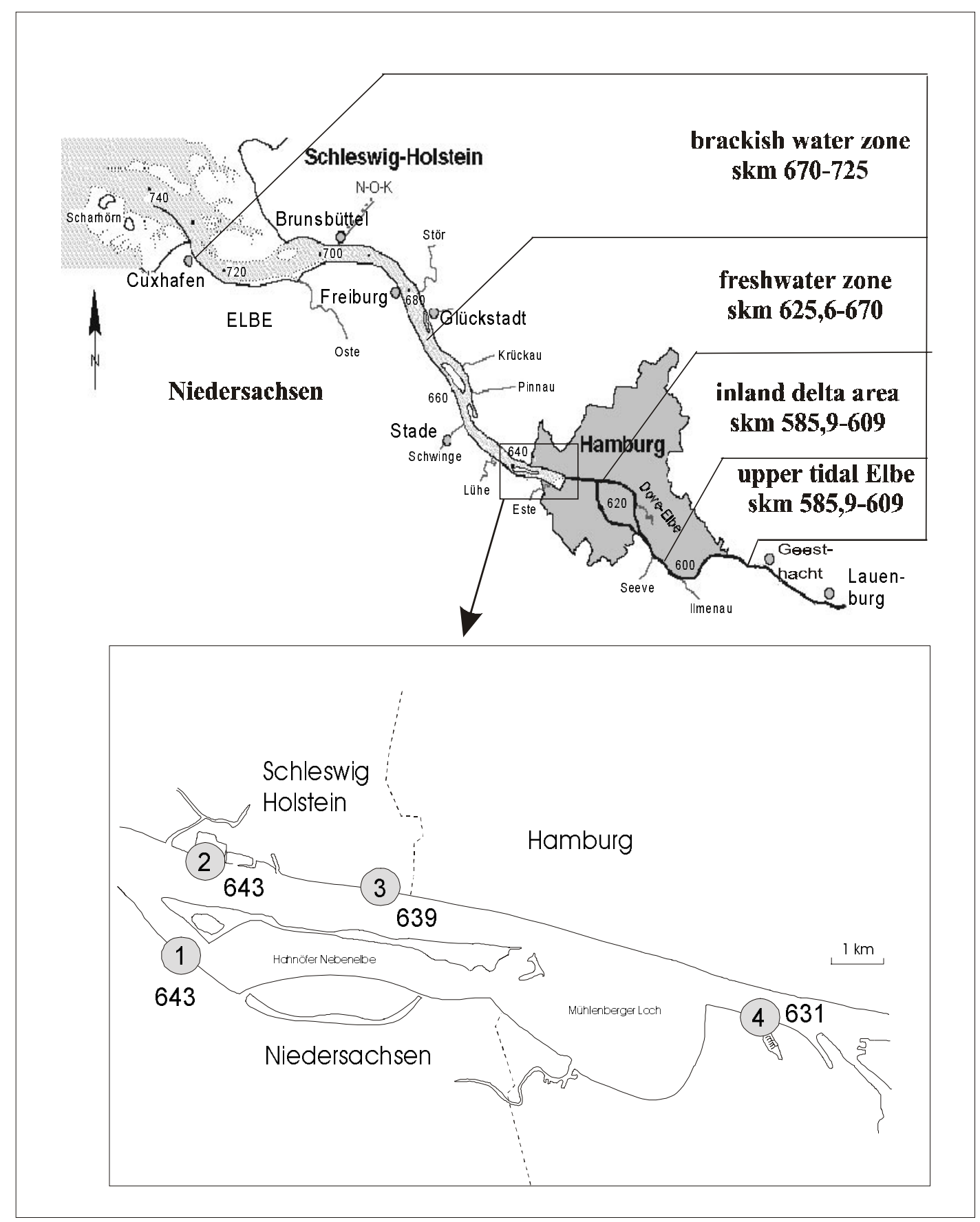

Figure 1

Map of the tidal Elbe River showing different zones and sampling sites (skm = stream kilometer).

\section{Figure 1}

Carte de l'estuaire de l'Elbe. Localisation des différents secteurs et des sites de pêche (skm : distance à la source en $\mathbf{k m}$ ). 


\section{Sampling}

Between April and August 1997 twaite shad larvae were sampled at four sites in the tidally influenced freshwater zone of the lower Elbe River downstream of the city of Hamburg (Figure 1). This region is believed to be the main spawning and nursery area of twaite shad (THIEL et al., 1996).

Three different types of sampling devices were used as follows : (i) A ring net with a mesh size of 500 and $1000 \mu \mathrm{m}$, an opening area of $0.694 \mathrm{~m}^{2}$ and a length of $2 \mathrm{~m}$. The net was pulled horizontally $15 \mathrm{~m}$ behind an inflatable. The net was trawled in circles to avoid water disturbance by the outboarder in front of the net opening (SEPULVEDA et al.,1993). The water flow through the gear was measured by a mechanical flow meter (General Oceanics) inserted in the opening of the net. (ii) A lift net of $1000 \mu \mathrm{m}$ mesh size, an opening area of $1 \mathrm{~m}^{2}$ and a length of $1.80 \mathrm{~m}$. The net was lifted vertically after 5 minutes exposure time (BAST et al., 1980). (iii) A pop net (buoyant net) of $1000 \mu \mathrm{m}$ mesh size and an opening area of $2.25 \mathrm{~m}^{2}$ triggered by a pull rope (Figure 2). The net pouch of this gear has a length of $2.40 \mathrm{~m}$ allowing quick lifting to reduce the net avoidance of larvae.
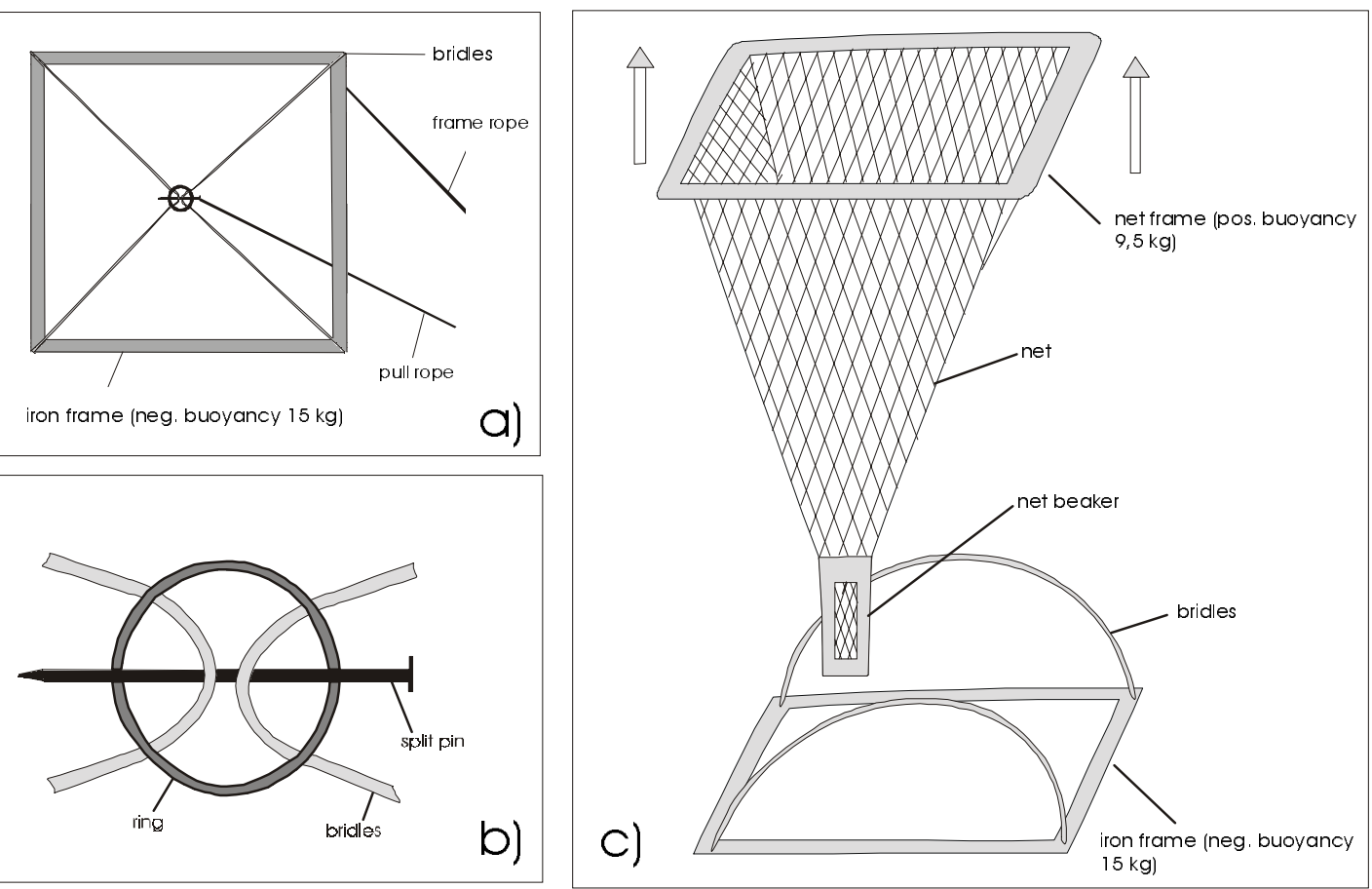

Figure 2

Scheme of the pop net (buoyant net). a) iron frame with bridles and release device, b) detailed diagram of the release device, c) net in release showing details of net construction.

\section{Figure 2}

Schéma du filet à ballast (filet «buoyant»). a) châssis de fer avec bridges et mécanisme de déclenchement, b) diagramme détaillé du mécanisme de déclenchement, c) filet déclenché avec détails de construction. 
The sampling took place twice a month. The sampling sites covered all the area of each of the investigated marinas and also the adjacent region. Each of the four sites was divided in two up to four compartments following a stratified random sampling strategy. One of the compartments covered the adjacent region in the side-or main channel at each site. The sampling area inside was divided in one to three compartments depending upon the distance between the river channel and the inner parts of a marina. In each compartment one ring net haul and 10 lift net hauls (from April to June) or 3 pop net hauls (in July) were taken. In July the pop net was used instead of the lift net because a significant decrease of the catch efficiency of lift nets occurs with increasing size of larvae (THIEL, 1996). A total of 976 samples was collected. Simultaneously with fish sampling, the environmental variables water temperature $\left({ }^{\circ} \mathrm{C}\right)$, conductivity $(\mu \mathrm{S} / \mathrm{cm})$, oxygen concentration $\left(\mathrm{mg}^{-1} \mathrm{l}^{-1}\right)$, water depth $(\mathrm{m})$, distance from shoreline $(\mathrm{m})$ and distance from river channel $(\mathrm{m})$ were measured with portable probes (WTW OXI 196 and LF 196) or taken from a detailed nautical map of the region.

\section{Analyses}

Caught larvae were preserved in $4 \%$ formaldehyde solution buffered with sodium borate. Later, they were counted, weighted (wet weight, accuracy $1 \mathrm{mg}$ ) and measured (total length, accuracy $0.1 \mathrm{~mm}$ ), in the lab. Frequency of occurrence (\%) and abundance (ind. $\mathrm{m}^{-3}$ ) were calculated. All samples from lift and pop net hauls in each compartment were pooled.

The suitability of different habitats like marinas, side channel and main channel as nursery area was compared by canonical correspondence analysis (TER BRAAK and SMILAUER, 1998). From the collected material all common species were included into the data matrix, i.e. asp (Aspius aspius), bleak (Alburnus alburnus), common bream (Abramis brama), flounder (Pleuronectes flesus), ide (Leuciscus idus), perch (Perca fluviatilis), pikeperch (Stizostedion lucioperca), roach (Rutilus rutilus), ruffe (Gymnocephalus cernuus), smelt (Osmerus eperlanus), ten-spined stickleback (Pungitius pungitius), three-spined stickleback (Gasterosteus aculeatus), twaite shad (Alosa fallax) and white bream (Abramis bjoerkna). Species with a frequency of occurrence less than $2 \%$ were excluded from further calculations to avoid a possible over-emphasis of rare species. The number of samples of the species matrix was reduced to non zero samples (195 samples $\times 14$ species). The number of samples of the environmental matrix was correspondingly reduced to 195 samples x 6 environmental variables. The ordination was computed with CANOCO 4.0 (TER BRAAK and SMILAUER, 1998). Species samples were square root transformed to reduce the over emphasis of large samples. Environmental data were centred according to JONGMAN et al. (1987) to make variables of different scale comparable.

The preference of larvae for each environmental variable was calculated for two different developmental stages (early larval stage ; late larval stage). The first stage comprises the substages A, B, C1, C2 and D1 according to VASNETSOV (1953) and includes larvae with total lengths from 7.1 to $17.2 \mathrm{~mm}$. The second stage corresponds to the substages D2 and E of VASNETSOV (1953) and includes larvae with total lengths from 15.4 to $29.1 \mathrm{~mm}$. All values of the environmental variables were grouped into intervals : water temperature $\left(17.0\right.$ to $18.5,18.6$ to $20.0,20.1$ to $21.5,21.6$ to $\left.23.0^{\circ} \mathrm{C}\right)$, conductivity (644 to 730,731 to 813,814 to 900,901 to $982 \mu \mathrm{S} / \mathrm{cm}$ ), oxygen concentration (4.8 to 7.0, 7.1 to $10.0,10.1$ to $13.3 \mathrm{mg} / \mathrm{l})$, water depth $(0.2$ to $2.5,2.6$ to $5.0,5.1$ to $10.0 \mathrm{~m})$, distance from shoreline $(7.5$ to 30,31 to 90,91 to $240 \mathrm{~m})$, distance from river channel (0 to 49,50 to $150,151$ to 400,401 to $754 \mathrm{~m})$. The data were grouped following the strategy that each of the categories of each of the variables should include the same number of values. Preference or avoidance of environmental variables were calculated as the difference between the frequency of larvae in one category of an environmental variable and the mean frequency of larvae in all categories of an environmental variable (COPP, 1992). 


\section{RESULTS}

\section{Occurrence, density and distribution}

Twaite shad larvae were found from 26 May 1997 to 10 July 1997 . Yolk sac larvae were present at the end of May and end of June, ranging from 7.1 to $8.8 \mathrm{~mm}$ total length (Figure 3). In contrast, no yolk sac larvae were found in the middle of June. This indicates the presence of a second spawning peak one month after the first peak in May, confirmed by the shape of the length frequency distribution of twaite shad larvae in June (Figure 3). In the middle of June the catches mainly contained early larval stages and just a few larvae of the late larval stage. At the end of June the catches comprised a mixing of small and older larvae which probably have their origins in the two different patches of spawning in May and June.
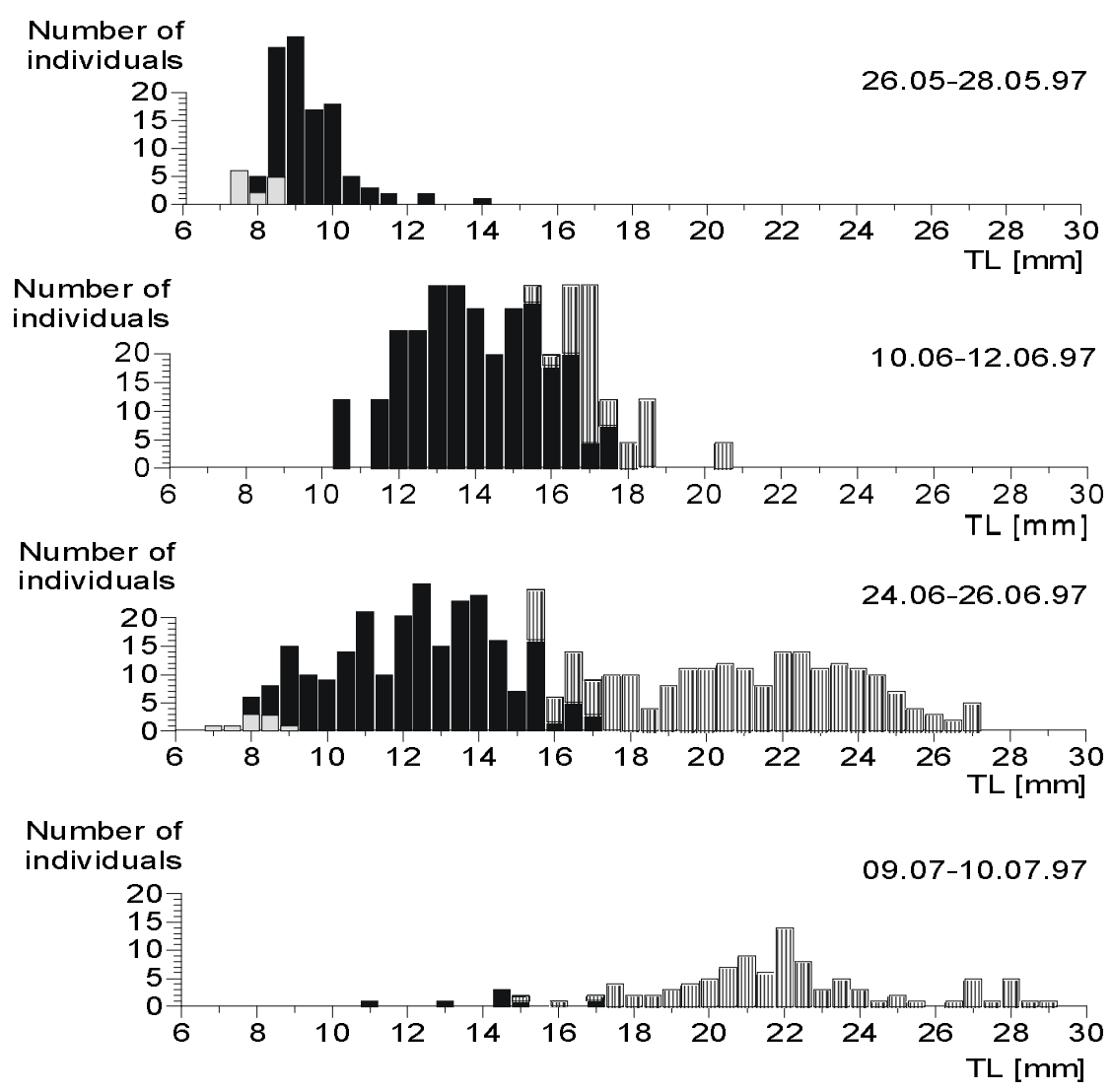

Figure 3

Length frequency distribution of twaite shad larvae from their nursery area in the Elbe River (stations 1 - 4) in 1997. Grey columns = yolk sac larvae ; black columns = early larval stage (without yolk sac larvae); stripped columns = late larval stage.

\section{Figure 3}

Histogramme des tailles des alevins d'alose feinte capturés dans les sites étudiés (stations 1 à 4) en 1997. Colonnes grises : larves vésiculées ; noires : premiers stades larvaires (hors larves vésiculées); striées: derniers stades larvaires. 
A mean water temperature of $17.8^{\circ} \mathrm{C}$ was measured at the time of the first observation of twaite shad larvae at the end of May. Most yolk sac larvae were found at station 4 (skm 631) in the main channel. However, the highest density of larvae with a mean of 203 ind. $100 \mathrm{~m}^{-3}$ occurred at side channel station 1 in June 1997 (Figure 4). At all sites larval abundance decreased following a spatial gradient from the mouth to the inner parts of marinas. Maximum density of twaite shad larvae was found in the side- and main channels outside of the marinas.

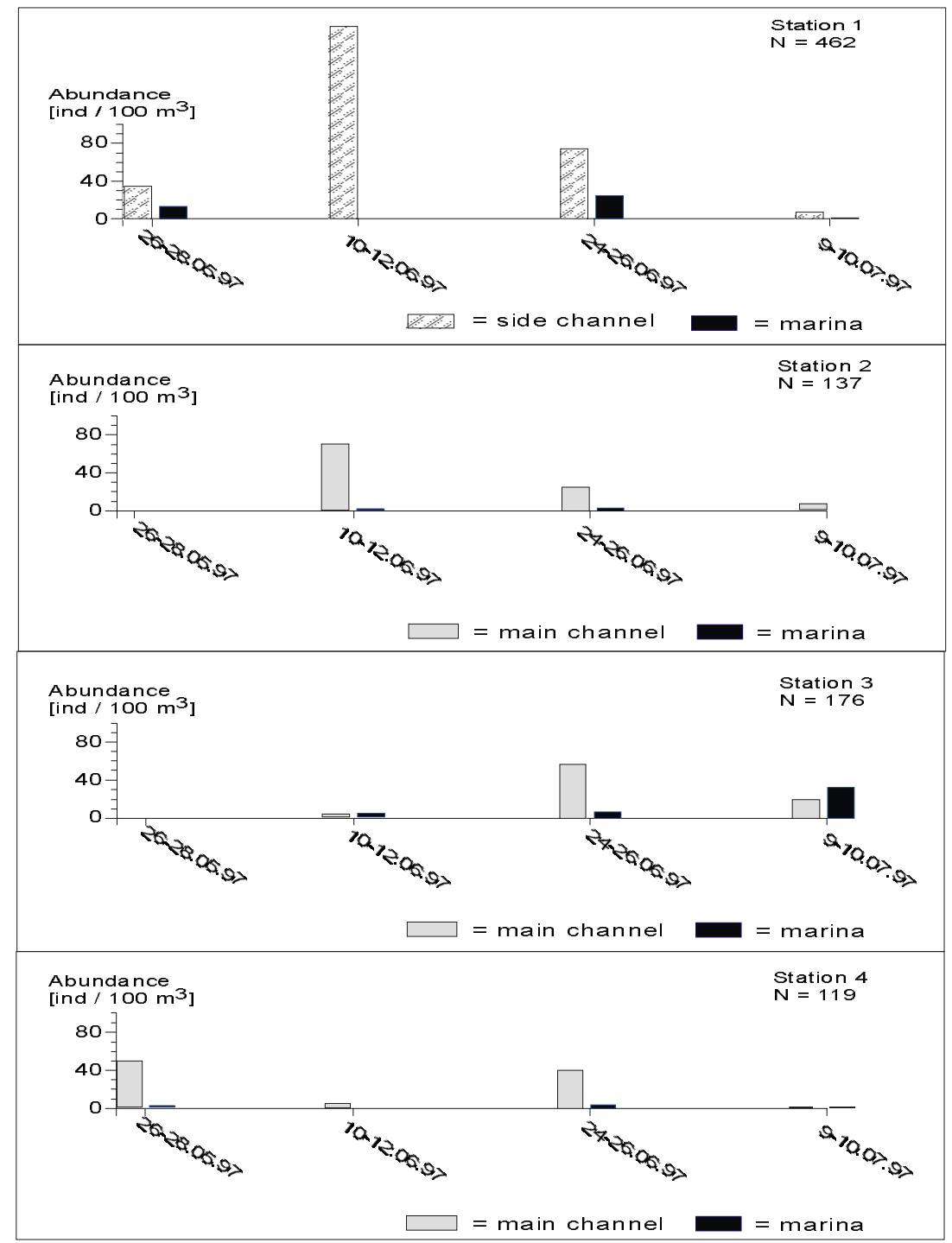

\section{Figure 4}

Mean abundance of larvae (ind. $100 \mathrm{~m}^{-3}$ ) at four sampling sites in the nursery area downstream of Hamburg. Grey columns = main channel ; black columns = marina ; stripped columns = side channel.

\section{Figure 4}

Densité moyenne (ind. $100 \mathrm{~m}^{-3}$ ) des alevins d'alose feinte capturés dans les sites en aval d'Hambourg. Colonnes grises : chenal principal ; noires : port ; striées : chenaux secondaires. 


\section{General community-level patterns}

A canonical correspondence analysis was performed to evaluate the importance of environmental variables for the species distribution (Figure 5). The vector length represents the importance of each variable. To identify the position of a species relative to another along a vector a vertical line must be drawn between the point representing the species and the arrow representing the variable. The rheophilic species twaite shad and smelt and the eurytopic percids pikeperch and ruffe grouped separately from eurytopic cyprinids and other species by water depth and distance from shoreline. Additionally, the twaite shad was separated from other rheophilic species by a smaller distance from the river channel. Unlike smelt, pikeperch and ruffe, the twaite shad larvae avoided marinas. A canonical correspondence analysis biplot of sampling sites and corresponding environmental variables clearly shows that marinas, side- and main channel are separated due to their environmental conditions (Figure 6). Water depth and distance from shoreline reached maximum values in the main channel which correspond with high water current. In contrast, water depth and distance from shoreline were much lower in marinas, corresponding with low water current. Side channels were intermediate.

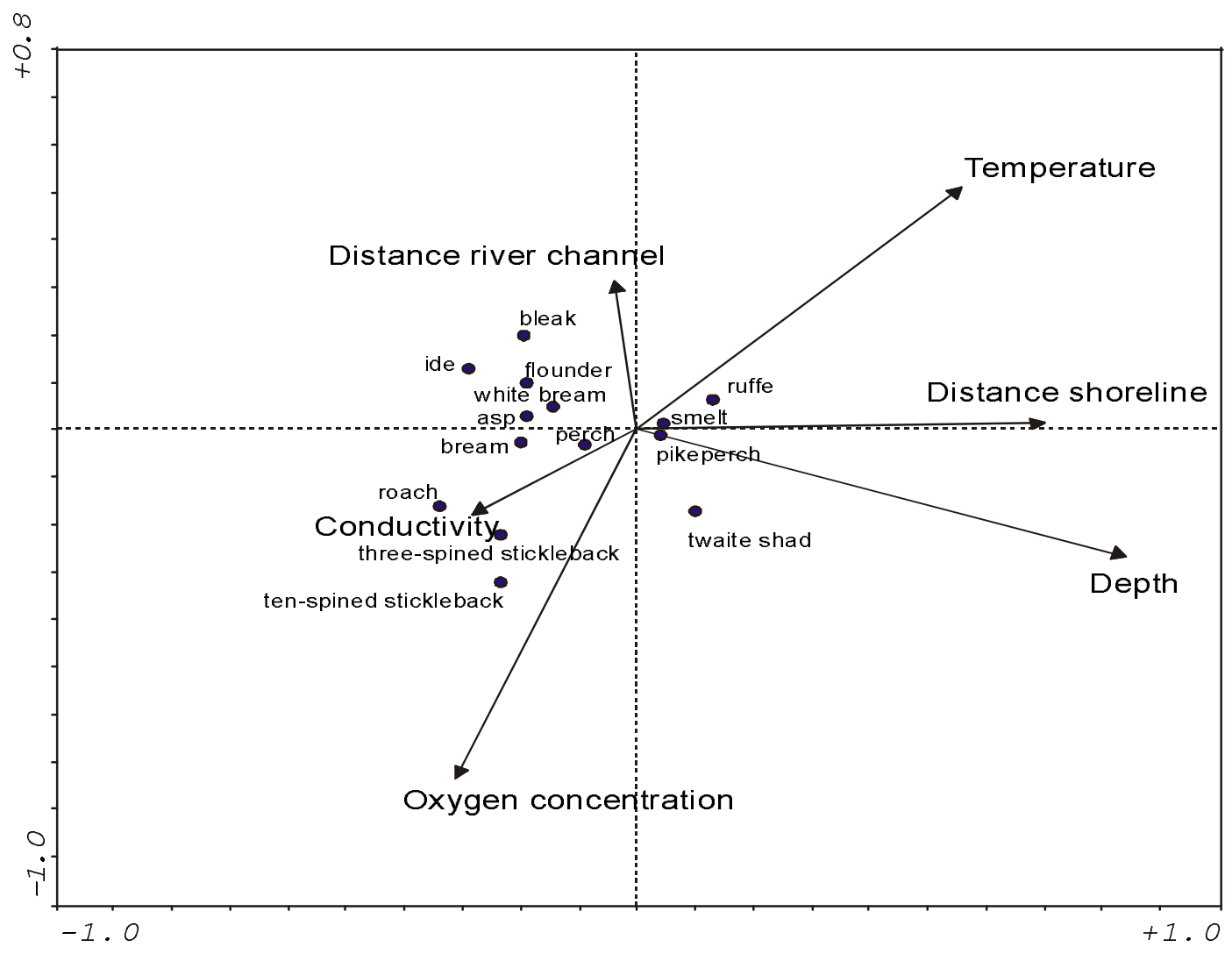

\section{Figure 5}

Canonical correspondence analysis (CCA) biplot of species distribution in relation to relevant environmental variables. Permutation test of significance of first canonical axis : F-ration $=6.551 ;$ P-value $=0.0066$.

\section{Figure 5}

Analyse canonique des correspondances : position des principales espèces de poissons dans l'espace des variables de milieu. Test de permutation de la significativité du premier axe : $F=6,551 ; P=0,0066$. 


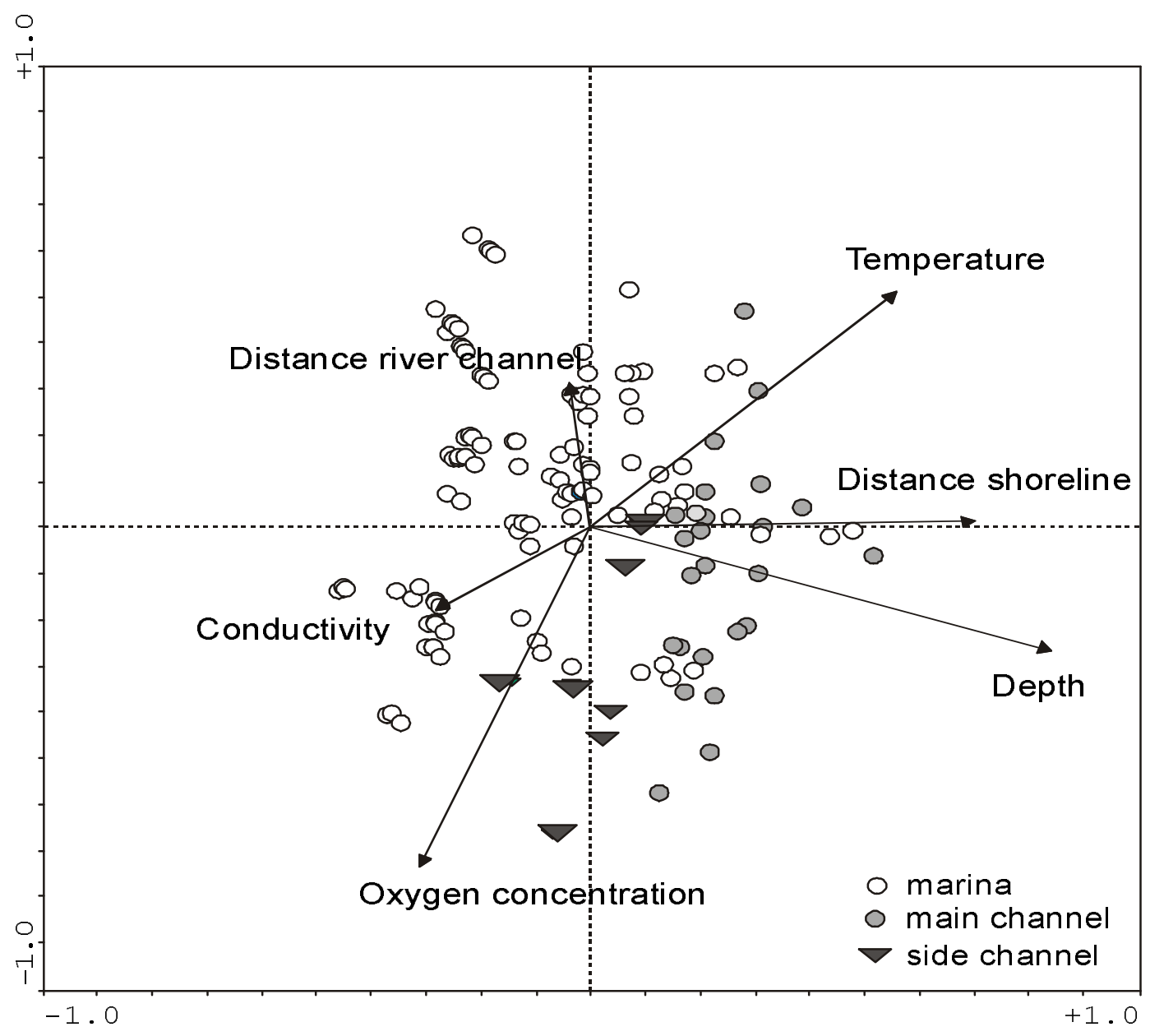

\section{Figure 6}

Sample site - environmental variables biplot calculated by canonical correspondence analysis (CCA). White dots = marina ; grey dots = main channel ; black triangle $=$ side channel.

\section{Figure 6}

Analyse canonique des correspondances : position des sites de pêches dans l'espace des variables de milieu. Points blancs : ports; points gris : chenal principal ; triangles noirs : chenaux secondaires.

\section{Habitat preference}

Small twaite shad larvae preferred temperatures between 17.0 to $20.0^{\circ} \mathrm{C}$, whereas older larvae preferred temperatures from 17.0 to $21.5^{\circ} \mathrm{C}$ (Figure 7). Higher temperatures were avoided. Relevant environmental variables indicating habitat suitability are water depth, distance from shoreline and distance from river channel. Generally, twaite shad larvae preferred maximum water depth and distance from shoreline. Shallow regions near the shore were avoided. Larval abundance reached maximum values at sites with short distances to the mainstream. The variables water temperature, conductivity, and oxygen concentration described differences in the seasonal occurrence of larvae. For instance, the early larval stage was present from May to June when water conductivity was between 
731 to $813 \mu \mathrm{S}$. Due to reduced discharge water conductivity was higher later in the year. This has led to an apparent preference of higher conductivity by the late larval developmental stage.
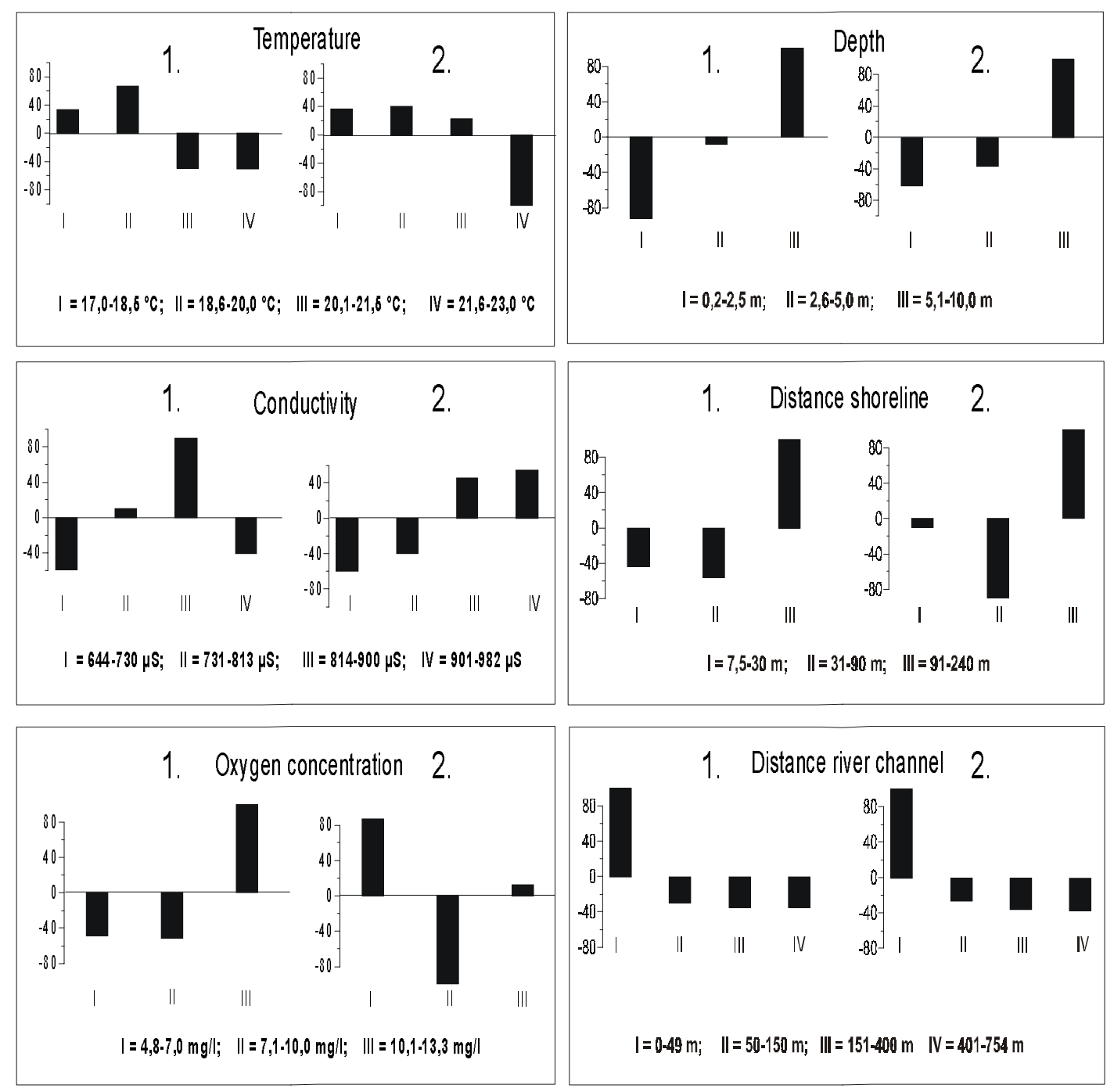

\section{Figure 7}

Preference indices of two developmental stages of twaite shad larvae for six environmental variables. Positive columns indicate preference and negative columns indicate avoidance for a specific variable. 1 = early larval developmental stage ; 2 = late larval developmental stage.

\section{Figure 7}

Diagrammes de préférence d'habitat de deux stades de développement ( $1=$ premier stade ; 2 = dernier stade) des alevins d'alose feinte pour six variables de milieu. Les fréquences positives (vers le haut) indiquent une préférence tandis que les fréquences négatives (vers le bas) indiquent un évitement. 


\section{DISCUSSION}

Numbers of individuals caught confirm the importance of the tidal freshwater region of the Elbe River as nursery area for twaite shad (e.g. THIEL et al., 1996). However, the catches inside marinas were much lower than outside in adjacent areas of the side- and main channels. Furthermore, the habitat preference indices indicate an avoidance of present habitat conditions in marinas which are characterised by shallower habitats, shorter distances to the bank and larger distances to the main channel. The number of larvae caught was higher in side channel habitats than in the main channel. The importance of side channel habitats as spawning and nursery areas can be attributed to better feeding conditions than in the main channel. Especially, the availability of one of the main prey for twaite shad larvae, the calanoid copepod Eurytemora affinis Poppe (OESMANN and THIEL, 2001), is much higher in side channel regions than in the main channel. KAFEMANN et al. (1996) reported that compared to the main channel the mean abundance of Eurytemora copepodids (249 ind. $\mathrm{I}^{-1}$ ) was 3 to 8 times greater in the side bay « Mühlenberger Loch » (skm 635).

The estimation of yolk sac larvae of twaite shad at station 4 (skm 631) indicates the presence of an actual spawning ground close to the area of larval catch. Since active upstream migration of yolk sac larvae can be excluded, it can be suspected that the spawning ground is located in the region " Hahnöfer Nebenelbe " and "Mühlenberger Loch " (between skm 643 and 633; Figure 1). This location is identical with the upper border of the spawning area of twaite shad reported in former times by EHRENBAUM (1894) and MOHR (1941). Between 1965 and 1986 a strong downstream displacement of the spawning grounds to skm 680-660 has been observed (HASS, 1968 ; MÖLLER and DIECKWISCH, 1991). WILKENS and KÖHLER (1977) mentioned water pollution as reason for this displacement. Additionally, the increase of water depth due to channelisation downstream of Hamburg, which cause increased mortality of river phytoplankton, has led to a depletion of oxygen (KAUSCH, 1992). However, since 1990 an improvement of water quality has been observed (REINCKE et al., 1992). THIEL et al. (1996) described an upstream displacement of twaite shad spawning grounds in the early 90th. During that period of time, the main spawning grounds were located approximately between skm 645 and 660. In May 2000 PEZENBURG (pers. comm.) observed mean egg densities $\left(0.013\right.$ ind. $\left.\mathrm{m}^{-3}\right)$ in the region « Mühlenberger Loch » which were comparable to those found with 0.007 ind. $\mathrm{m}^{-3}$ close to the water surface by HASS (1968) in the former main spawning region more downstream. The larval densities amounted to 35.3 ind. $\mathrm{m}^{-3}$ in the "Mühlenberger Loch » in the middle of May 2000. This value was two times higher than the maximum larval densities earlier observed by MÖLLER (1988) more downstream in the Elbe estuary and about 25 times higher than the 0.14 ind. $\mathrm{m}^{-3}$ estimated by THIEL et al. (1996) in the "Mühlenberger Loch ». These findings indicate that the main spawning and nursery area of twaite shad in the Elbe River extends upstream to skm 635 nowadays.

\section{REFERENCES}

BARTL G., TROSCHEL H., 1997. Historical distribution, population development and actual situation of Alosa alosa and A. fallax in the River Rhine area. Z. Fischk., 4, 119-162.

BAST H.D., FADSCHILD K., MÖNKE E., 1980. Orientierende Untersuchungen zum Jungfischaufkommen im Bereich des Barther Boddens im Juni 1979. Wiss. Z. Univ. Rostock N-Reihe, 29, 99-102.

CASWELL P., APRAHAMIAN M.W., 2001. Use of River Habitat Survey to determine the spawning habitat characteristics of twaite shad (Alosa fallax fallax). Bull. Fr. Pêche Piscic., 362/363, 919-929.

COPP G.H., 1992, An empirical model for predicting microhabitat of $0+$ juvenile fishes in a lowland river catchment. Oecologica, 91, 338-345. 
EHRENBAUM E., 1894, Beiträge zur Naturgeschichte einiger Elbfische. Helgl. Wiss. Meeresunters., 1, 35-79.

HASS H., 1968. Untersuchungen über die vertikale und horizontale Verteilung der Eier der Finte, Alosa fallax (Lacépède 1803), in der Elbe. Arch. Fischereiwiss., XIX, 1, 4655.

JONGMAN R.H.G., TER BRAAK C.J.F., VAN TONGEREN O.F.R., 1987. Data analysis in community and landscape ecology. Pudoc, Wageningen.

KAFEMANN R., THIEL R., SEPULVEDA A., 1996. Die fischökologische Bedeutung der Nebenstromgewässer der Unterelbe. Arch. Hydrobiol./Suppl., 110, 199-214.

KARTAS F., 1981. The Clupeidae of Tunisia : their biometrical and biological characteristics, a comparative study of eastern Atlantic and Mediterranean populations. Dissertation, Tunis-Univ., $608 \mathrm{p}$.

KAUSCH H., 1992. Die Unterelbe. Natürlicher Zustand und Veränderungen durch den Menschen. Berichte aus dem Zentrum für Meeres- und Klimaforschung, Hamburg, $19,1-260$.

MAY R.C., 1974. Larval mortality in marine fishes and the critical period concept. In BLAXTER J.H.S. (ed.), The early life history of fish, Springer, New York, 3-19.

MOHR E., 1941. Maifische. In DEMOLL R., (ed.), Handbuch der Binnenfischerei Mitteleuropas, Schweizerbart'sche Verlagsbuchhandlung, Stuttgart, III A, 527-551.

MÖLLER, H. ,1988. Fischbestände und Fischkrankheiten in der Unterelbe 1984 - 1986. Möller, Kiel, $344 \mathrm{p}$.

MÖLLER H., DIECKWISCH B., 1991. Larval fish production in the tidal River Elbe 19851986. J. Fish. Biol., 38, 829-838.

OESMANN S., THIEL R., 2001. Feeding of juvenile twaite shad (Alosa fallax Lacépède, $1803)$ in the Elbe Estuary. Bull. Fr. Pêche Pisic., 362/363, 785-800.

QUIGNARD J.P., DOUCHEMENT C., 1991a. Alosa fallax fallax (Lacépède, 1803). In HOESTLAND H. (ed.), The Freshwater Fishes of Europe, AULA-Verlag, Wiesbaden, 2, 225-253.

QUIGNARD J.P., DOUCHEMENT C., 1991b. Alosa fallax rhodanensis (Roule, 1924). In HOESTLAND H. (ed.). The Freshwater Fishes of Europe, AULA-Verlag, Wiesbaden, 2, 274-296.

REINCKE H., LISCHKE P., SCHINDLER J., 1992. Vorstellung der Ergebnisse der Arbeitsgruppe "Meß- und Untersuchungsprogramme » der Internationalen Kommission zum Schutz der Elbe. Proceedings of the «4. Magdeburger Gewässerschutzseminar », 275-282.

SEPULVEDA A., THIEL R., NELLEN W., 1993. Distribution patterns and production of early life stages of European smelt, Osmerus esperlanus L., from the Elbe River. ICES C.M. 1993/ M, 29, 22 p.

TAVERNY C., 1991. Pêche, biologie, écologie, des aloses dans le système GirondeGaronne-Dordogne. Dissertation, Bordeaux Univ., 384 p.

TER BRAAK C.J.F., SMILAUER P., 1998. CANOCO reference manual and user's guide to Canoco for Windows : Software for canonical community ordination (version 4). Microcomputerpower (Ithaca. NY, USA), $352 \mathrm{p}$.

THIEL R. 1996. The impact of fish predation on the zooplankton community in a southern Baltic bay. Limnologica, 26, 123-137.

THIEL R., SEPULVEDA A., OESMANN S., 1996. Occurrence and distribution of twaite shad (Alosa fallax) in the lower Elbe river, Germany. In KIRCHHOFER A. and HEFTI D. (Eds.), Conservation of Endangered Freshwater Fish in Europe, Birkhäuser Verlag, Basel, 157-170.

VASNETSOV V.V., 1953. Developmental stages of teleosts. Essays on general problems of ichthyology. Moscow Izd-vo AN SSSR, $217 \mathrm{p}$.

WILKENS H., KÖHLER A., 1977. Die Fischfauna der unteren und mittleren Elbe : die genutzten Arten, 1950-1975. Abhandlungen und Verhandlungen des naturwissenschaftlichen Vereins zu Hamburg, 20, 185-222. 